\title{
ANTOLOGIA DE TEXTOS EM PORTUGUÊS QUE SE FALAM
}

\author{
Tiago Martins Aires \\ Doutorando na Universidade de Santiago de Compostela, \\ membro do grupo GALABRA - USC. \\ aires.tiago.martins@gmail.com
}

\section{RESENHA}

BUESCU, Helena Carvalhão; MATA, Inocência (Org.). Literatura-Mundo Comparada, Perspetivas em Português, Parte I: Mundos Em Português, vols. 1 e 2. Lisboa: Tinta da China, 2018.

Resultante de um projeto do Centro de Estudos Comparatistas (CEC), sediado na Faculdade de Letras da Universidade de Lisboa (FLUL), esta antologia, agora publicada pela Tinta da China em dois volumes, mereceu o financiamento da Fundação para a Ciência e a Tecnologia e com o "Alto Patrocínio da Sua Excelência o Presidente da República", Marcelo Rebelo de Sousa, o que evidencia, desde logo, a sua importância e capital simbólico de dar a conhecer visões sobre o mundo, neste caso, em português.

Apesar da sua origem de base científica e universitária, a antologia tem como objetivo declarado ser partilhada com uma comunidade mais abrangente: "a de todos quantos leem em português" (BUESCU, 2018, p.23), daí que seja de louvar que tenha sido uma editora genérica como a Tinta da China, e não uma editora universitária, quem publicou o resultado, permitindo uma maior visibilidade para um público geral e nãoacadémico.

Com o objetivo de "oferecer ao leitor um conjunto significativo de textos escritos nas várias literaturas de língua portuguesa" (BUESCU, 2018, p.31), esta primeira parte da 
antologia centra-se nos "Mundos em Português" e estende-se por dois volumes organizados em torno de temas aglomeradores de textos de autores de diversas proveniências temporais e geográficas com "literaturas escritas originalmente em português, ou seja, a literatura portuguesa (desde a Idade Média até ao presente), a literatura brasileira, as cinco literaturas africanas de língua portuguesa e as outras com origem em diversos pontos do planeta como Goa, Macau ou Timor-Leste" (BUESCU, 2018, p.26). Na totalidade, a antologia terá sete volumes, pois haverá mais dois dedicados à literatura europeia e outros três sobre a literatura dos restantes continentes - mas esta recensão tratará apenas os dois primeiros volumes.

Como qualquer antologia, este livro resulta de critérios de seleção mais ou menos subjetivos, de gostos e de perspetivas pessoais. Neste caso, os critérios foram negociados pelo coletivo do grupo de investigação e, para maior clareza, explicitados na "Introdução Geral": "este conjunto de antologias exprime o ponto de vista de uma equipa organizada historicamente situada em Portugal" (BUESCU, 2018, p.25), constituída por professores de literatura da FLUL e do CEC "que olha para o mundo, no início do século XXI" (BUESCU, 2018, p.25), constituindo uma visão particular de um grupo que vive em português. Desta forma, os antologiadores não se escondem no anonimato, mas participam ativamente da obra apresentada: "É nossa convicção que este tipo de antologias dá a ler não apenas o objeto por si constituído (os textos selecionados), mas também o ponto de vista de quem constitui o objeto" (BUESCU, 2018, p.25). Essa subjetividade implica ainda que a mudança das variáveis tempo, espaço, colaboradores resultaria em antologias diferentes entre si. É, então, uma proposta - válida, mas que não se esgota.

Cada contributo se norteou pela seleção de textos que, de alguma forma, permitem uma aproximação entre eles, uma perspetiva comparatista, cruzamentos e 
descoberta de perspetivas afins ou contrárias. Ou seja, o projeto "Literatura-Mundo Comparada" parte de uma visão comparatista que encara os textos por si mesmos, mas, sobretudo, pelos diálogos que podem estabelecer entre si, anulando ou esbatendo fronteiras que poderiam ser acentuadas pelas diferentes proveniências autorais.

Assim, o critério de organização não poderia ser nem cronológico nem geográfico, mas antes um critério temático: encontramos textos de diferentes autores, aparentemente tão distantes como Afonso X, José Eduardo Agualusa ou Manuel Alegre logo na abertura do primeiro tema. Ora, isto acontece porque esses temas organizadores são os seguintes: Conflito e Violência, Memória e Vida, Humor, Sátira e Ironia, Poesia sobre Poesia, e Viagens e (Des)Conhecimento do Outro, no primeiro volume, e Amor e Experiência, História e Identidade, Cartografias da Tradição, Literatura e Condição Humana e Língua e Variação (este último, plenamente justificado por ser a língua portuguesa um critério-base na seleção dos textos), no segundo. Não há uma indicação clara das razões para cada um destes temas, mas resultam de uma discussão entre mais de 60 colaboradores que os escolheram de forma a permitir uma certa abrangência e, ao mesmo tempo, "porosidade constante" (BUESCU, 2018, p.32), uma relação entre os textos em cada eixo temático, mas também com os textos dos outros temas.

Relativamente aos autores selecionados, nada é indicado sobre a sua relevância, papel na construção do cânone das diferentes literaturas nacionais, apenas que são autores que começaram a publicar antes do ano de 2000 (data-limite fixada pelo grupo), de qualquer forma, subentende-se que, ao entregar-Ihes espaço na antologia, os organizadores reconhecem qualidade, valor ou importância a cada um dos autores e textos, sejam eles mais ou menos conhecidos do grande público ou mesmo de públicos mais especializados. A única exceção é feita relativamente à obra Os Lusíadas, de Luís Vaz 
de Camões, cujos excertos se encontram em todos os eixos temáticos e de quem se afirma que é "texto matricial também da literatura-mundo" (BUESCU, 2018, p.27) ou apresenta uma "posição fundadora numa visão das literaturas em português enquanto literatura-mundo" (BUESCU, 2018, p.33). Assim, surgem autores muito conhecidos do público leitor português, como; Sophia de Mello Breyner Andresen, Raúl Brandão, José Saramago, Lídia Jorge, Mia Couto, ao lado de autores menos familiares, como: Nito Mesquinho, Vimala Devi, Yao Feng, Vera Duarte, entre outros. Nota ainda para a "Lista de Impossíveis", onde se elenca uma série de textos e autores que, por diferentes motivos (não revelados) não puderam ser incluídos na antologia, com pesar dos organizadores. Relativamente aos géneros textuais, é também de destacar que todos os géneros foram admitidos na antologia: poesia, contos, excertos de romances e de textos dramáticos, crónicas, literatura de viagens, etc.

Se numa seleção sempre se pode discutir a ausência/presença de determinado autor ou texto - discussões nem sempre úteis ou simpáticas - porque selecionar significa incluir, mas também excluir, nesta antologia gostaria apenas de problematizar a "leitura cruzada dos textos" (BUESCU, 2018, p.32) que é deixada ao leitor: "melhor diríamos, diferentes formas de diálogo, que contam com a participação ativa interpretativa do leitor para ser ativadas" (BUESCU, 2018, p.28). É nele que a equipa de antologiadores deixa o trabalho de fazer as possíveis comparações que que presidiram à organização apresentada. Faria falta, talvez, orientar um pouco mais os possíveis leitores, oferecendo pistas em notas de rodapé ou num apêndice, uma vez que cada leitor é diferente e, de acordo com a sua enciclopédia e experiências literárias poderá obter maior ou menor proveito da leitura da antologia. As "Notas Críticas" apresentadas no final do segundo 
volume, apresentam alguns aspetos biobibliográficos, mas não cumprem o papel de abrir os textos para leituras comparadas.

Ainda assim, Mundos em Português apresenta-se como uma antologia de exceção, provinda de uma equipa de leitores que é também especialista em estudos literários, fez uma seleção baseada em critérios sólidos e diferentes do habitual, para apresentar ao vasto público uma série de textos para ver e pensar o mundo e que poderá ser decisiva para a sociedade em que ela irrompe e se impõe.

Recebido em 21 de março de 2019.

Aceito em 01 de abril de 2020. 